\title{
The effect of fertilization and plant protection on sunflower (Helianthus annuus L.) production
}

\author{
Zoltán Futó \\ Szent István University, Faculty of Agricultural and Economic Studies, Tessedik Campus \\ 5540 Szarvas, Szabadság street. 1-3. \\ futo.zoltan@gk.szie.hu
}

SUMMARY

\begin{abstract}
Sunflower is the most important oil crop in Europe which is grown on the biggest area of all oil crops. The area of producing sunflowers in Hungary changed from 524 to 704 thousand hectares in the past decade in comparison with approximately 100 thousand hectares in the 1970's. In our experiment, different sunflower hybrids were examined. The following fertiliser doses were applied in 2017 and 2018: 0-3090-150 kg ha-1 N, 0-50-90-90 kg ha-1 $P_{2} \mathrm{O}_{5}$ and 0-70-110-110 $\mathrm{kg} \mathrm{ha}^{-1} \mathrm{~K}_{2} \mathrm{O}$. Three different treatments of plant protection were used in the experiment to protect them from fungal infections. A rise in the dosage of nitrogen resulted in increasing infection. The biggest fungal infection was identified in the case of $150 \mathrm{~kg} \mathrm{ha}^{-1} \mathrm{~N}, 90 \mathrm{~kg} \mathrm{ha}^{-1} P_{2} \mathrm{O}_{5}$ and $110 \mathrm{~kg} \mathrm{ha}^{-1} \mathrm{~K}_{2} \mathrm{O}$. The largest infection was measured on plots without plant protection at the highest $N$ doses, both in the case of leaf and disc diseases. We measured the highest value of Diaporthe helianthi infection of $41.25 \%$ in 2017 and of $53.1 \%$ in 2018, and Sclerotinia sclerotiorum disc infection of $24.5 \%$ in 2017 and of $25.5 \%$ in 2018 in these plots. Average yield ranged between 2.96-4.67 $\mathrm{ha}^{-1}$ in 2017 and 2018. The lowest yield was obtained in the absolute control plot (without plant protection and without nutrient replenishment) in both years, which was $2.96 \mathrm{tha^{-1 }}$ in 2017 and $3.14 \mathrm{t} \mathrm{ha}^{-1}$. Yields increased due to growing

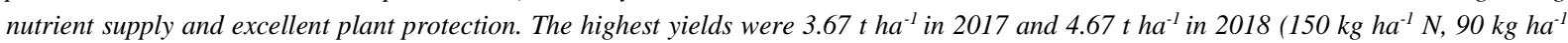
$\mathrm{P}_{2} \mathrm{O}_{5}$ and $110 \mathrm{~kg} \mathrm{~K} \mathrm{~K}_{2}$ active substance). The purpose of the experiment is analysing the impact of different treatments on the profitability of sunflower production.
\end{abstract}

Keywords: sunflower, plant protection, nutrient supply

\section{INTRODUCTION}

Sunflower is the most important oil crop in Hungary. When deciding on the amount of nitrogen a special attention must be paid to the fact that overdosing may lead to the plant's increased susceptibility to fungal infections, reduced oil content but, at the same time, the lack of it can result in reaching the yield targeted. Phosphorus increases both piling up dry matter and oil content. Potassium increases resistance to diseases and tolerance to drought (Ivány, 1994).

Nitrogen decreases the oil content of the achene but, on the other hand, it increases yield per hectare. Phosphorus increases both piling up dry matter and oil content. However, potassium increases the plant's resistance to the environment, improves its drought tolerance, resistance to diseases and even decreases the effect of nitrogen overdose (Radics, 2003).

According to Novak (2013), fungal infections have a major effect on the average yield of sunflower. In your experiments Diaporthe infections was stronger in 2011 while in 2012 Sclerotinia infections were greater than average. Higher plant density provided for a favorable microclimate for pathogens meaning that increased stock density enabled enhanced infections. Maximum levels of infections in both the cases of Diaporthe and Sclerotinia were measured at a plant density level of 65000 plants ha ${ }^{-1} .2012$ yields (control: between 2289 and $3261 \mathrm{~kg} \mathrm{ha}^{-1}$, two-time treated: between 2699 and $3659 \mathrm{~kg} \mathrm{ha}^{-1}$ ) were significantly lower compared to the results of 2011 (control: between 2825 and $3672 \mathrm{~kg} \mathrm{ha}^{-1}$, two-time treated: between 3 059 and $4059 \mathrm{~kg} \mathrm{ha}^{-1}$ ). Fungicide treatments led to an increased yield in both years: $9.5 \%$ in 2011 and a notable, $15.1 \%$ growth in 2012.

Thavaprakash et al. (2003) found, that due to the higher number of green leaves, higher LAI and greater dry matter accumulation in the leaves, the treatments with an N/P ratio of $>1.0$ or 1.0 with $120 \mathrm{~kg} \mathrm{~N} \mathrm{ha}^{-1}$ produced higher seed yields (3188 to $3554 \mathrm{~kg} \mathrm{ha}^{-1}$ ) than other N/P ratios (2761 to $3009 \mathrm{~kg} \mathrm{ha}^{-1}$ ). The highest yield $\left(3554 \mathrm{~kg} \mathrm{ha}^{-1}\right)$ was recorded with an N/P ratio of 1.0 in the treatment receiving $120 \mathrm{~kg} \mathrm{~N}$ and $120 \mathrm{~kg} \mathrm{P}_{2} \mathrm{O}_{5}$ $\mathrm{ha}^{-1}$. The correlation coefficients between these photosynthetic attributes and seed yield were also positive and significant.

Intensive nutrient supply, especially increasing $\mathrm{N}$ dose are favourable for infections (Futó, 2013). In experiment found, that both plant protection and nutrient supply could result in significant differences in the infection values of Diaporthe helianthi and Sclerotinia sclerotiorum. Also concluded from the experiment that plant protection and nutrient supply significantly influenced yields that could be reached. Optimal nutrient supply and professional plant protection also led to significant yield increases in the year of the examination.

Several studies on the nutrient requirements of sunflower indicated that, among the macro-nutrients, nitrogen and phosphorus are likely to be the primary limiting nutrients in sunflower under most environments (Devidayal and Agarwal, 1998; Dhoble, 1998; Mallikarjuna et al., 2000).

The optimal $\mathrm{N}$ dose of sunflower hybrids with different genotypes is also different That is why using hybrid specific $\mathrm{N}$ fertilising techniques is very important in the case of new sunflower genotypes 
(Pepó and Zsombik, 2003). Hall et al. (1995) tested the Prosol 35 hybrid with 2,4 plant $\mathrm{m}^{-2}$ crop density with and without supplying $\mathrm{N}\left(5 \mathrm{~g} \mathrm{~N} \mathrm{~m}^{-2}\right)$. Both nitrogensupplies induced increase in biomass with increasing plant number, and LAI.

Optimum fertilizer management can result in a twofold increase in the seed yield of sunflower (Chorey and Thosar, 1997).

Futó (2008) concluded that a significantly greater infection is generated on higher plant density. The steamier microclimate formed in the case of more stems provides favourable conditions for generating Diaporthe leaf and stem infections as well as Scleroitinia stem and disc florets infections. Sunflower is susceptible to some fungal infections but today there are such existing hybrids that show a significant resistance or tolerance on arable land. Vear and Tourvieille (1984) note it with a regret that the oil content of several resistant genotypes is low so resistance is inversely related to yield or earliness.

\section{MATERIALS AND METHODS}

In 2017 and 2018, the average amount of precipitation was similar however, the two years were very different. In July and August 2017 the precipitation was less $68.9 \mathrm{~mm}$, as the 30-year average. In all year was $72.8 \mathrm{~mm}$ less rainfall than the 30 -year average. The few rainfall was very unfavourable. The leaf and disc infection was also a low level. In 2018 a lot of precipitation fell before sowing, so the soil was very wet and difficult to cultivate. Then the precipitation was reduced throughout the growing season, as the 30-year average, but in July and August the precipitation was more favourable than in 2017 , so the yield of sunflower was more in 2018 than 2017. In 2018 , leaf and disc infections were an average rate. (Table 1).

Precipitation data between January 2017/2018 and September 2017/2018, Szarvas

\begin{tabular}{|c|c|c|c|c|c|c|c|c|c|c|}
\hline Month & Jan & Feb & March & April & May & June & July & Aug & Sept & Total \\
\hline Precipitation $2017(\mathrm{~mm})$ & 28.3 & 30.2 & 13.4 & 49.7 & 40.9 & 69.3 & 31.8 & 33.3 & 74.2 & 371.1 \\
\hline Different in $2017(\mathrm{~mm})$ & -2.3 & -1.2 & -15.5 & 7.8 & -22.0 & -2.1 & -42.6 & -26.3 & 31.4 & -72.8 \\
\hline Precipitation $2018(\mathrm{~mm})$ & 18.3 & 70.3 & 75.2 & 11.2 & 37.4 & 31.0 & 69.8 & 43.9 & 14.5 & 371.6 \\
\hline Different in $2018(\mathrm{~mm})$ & -12.3 & 38.9 & 46.3 & -30.7 & -25.5 & -40.4 & -4.6 & -15.7 & -28.3 & -72.3 \\
\hline 30 year-average & 30.6 & 31.4 & 28.9 & 41.9 & 62.9 & 71.4 & 74.4 & 59.6 & 42.8 & 443.9 \\
\hline
\end{tabular}

The experiment was carried out on non-carbonate chernozem brown forest soil where topsoil had acid reaction $\left(\mathrm{pH}_{\mathrm{KCl}} 4.59\right)$ Table 2 . The cultivated topsoil is of clay and adobe with slight acid reaction (the value of hydrolyte acidity is slight and replacement acidity can be ignored). Its humus content is a bit higher than average and its total salt content is low. The entire soil section is free from carbonates. Acidity gradually and slightly decreases in parallel with depth.

Table 2

The main characteristics of soil on the experimental area

\begin{tabular}{ccccccccc}
\hline Level & $\begin{array}{c}\text { depth } \\
(\mathrm{cm})\end{array}$ & $\mathrm{KA}$ & $\begin{array}{c}\mathrm{pH} \\
\left(\mathrm{H}_{2} \mathrm{O}\right)\end{array}$ & $\begin{array}{c}\mathrm{pH} \\
(\mathrm{KCl})\end{array}$ & $\begin{array}{c}\mathrm{CaCO}_{3} \\
\%\end{array}$ & $\mathrm{y}_{1}$ & $\mathrm{y}_{2}$ & $\mathrm{Humus} \%$ \\
\hline $\mathrm{A}_{\mathrm{sz}}$ & $0-30$ & 42 & 6.27 & 4.59 & 0 & 8.71 & 0.40 \\
$\mathrm{~A}_{2}$ & $30-45$ & 58 & 6.13 & 4.42 & 0 & 8.30 & 0.61 & 2.69 \\
$\mathrm{~B}_{1}$ & $45-60$ & 67 & 6.22 & 4.52 & 0.12 & 6.28 & 0.81 & 1.90 \\
$\mathrm{~B}_{2}$ & $60-80$ & 68 & 6.41 & 4.64 & 0 & 4.25 & 0.30 & 1.47 \\
$\mathrm{C}_{1}$ & $80-135$ & 71 & 6.74 & 4.93 & 0 & 3.85 & 0.30 & 0.79 \\
\hline
\end{tabular}

Three nutrient levels were created on the experimental area by adding a control plot receiving no chemical fertilizer treatments. On the basis of these points the nutrient levels were the following:

- Nutrient treatment I.: $0 \mathrm{~kg} \mathrm{ha}^{-1} \mathrm{~N}, 0 \mathrm{~kg} \mathrm{ha}^{-1} \mathrm{P}_{2} \mathrm{O}_{5}$ and $0 \mathrm{~kg} \mathrm{~K}_{2} \mathrm{O}$ active substance

- Nutrient treatment II: $30 \mathrm{~kg} \mathrm{ha}^{-1} \mathrm{~N}, 50 \mathrm{~kg} \mathrm{ha}^{-1} \mathrm{P}_{2} \mathrm{O}_{5}$ and $70 \mathrm{~kg} \mathrm{~K}_{2} \mathrm{O}$ active substance

- Nutrient treatment III: $90 \mathrm{~kg} \mathrm{ha}^{-1} \mathrm{~N}, 90 \mathrm{~kg} \mathrm{ha}^{-1} \mathrm{P}_{2} \mathrm{O}_{5}$ and $110 \mathrm{~kg} \mathrm{~K}_{2} \mathrm{O}$ active substance

- Nutrient treatment IV: $150 \mathrm{~kg} \mathrm{ha}^{-1} \mathrm{~N}, 90 \mathrm{~kg} \mathrm{ha}^{-1}$ $\mathrm{P}_{2} \mathrm{O}_{5}$ and $110 \mathrm{~kg} \mathrm{~K} 2 \mathrm{O}$ active substance
The possibilities of technological improvement of three fungicide combinations were examined in the experiment by adding a control plot without being treated with a fungicide treatment. The basic fungicide in the examination was boscalide $200 \mathrm{~g} \mathrm{l}^{-1}+$ dimoxystrobine $200 \mathrm{~g} \mathrm{l}^{-1}$ (with $0.51 \mathrm{ha}^{-1}$ dosage) mixed with two technological development combination partners (pyraclostrobin and azoxystrobin in the experiment. The first treatment were received by the sunflowers in the state of having $8-10$ leaves $(\mathrm{BBCH}$ 18-19.) while the second ones were applied when 
sunflowers developed a before of flowering $(\mathrm{BBCH}$ 57-59.). Treatments were as follows:

- Control: (plots without fungicide technology)

- 'A' Plant protection: $100 \mathrm{~g} \mathrm{ha}^{-1}$ boscalide +100 $\mathrm{g} \mathrm{ha}^{-1}$ dimoxystrobin (BBCH 18-19.) + $100 \mathrm{~g} \mathrm{ha}^{-1}$ boscalide $+100 \mathrm{~g} \mathrm{ha}^{-1}$ dimoxystrobin (BBCH 5759.)

- 'B' Plant protection: pyraclostrobin $50 \mathrm{~g} \mathrm{ha}^{-1}$ (BBCH 18-19.) + $100 \mathrm{~g} \mathrm{ha}^{-1}$ boscalide $+100 \mathrm{~g} \mathrm{ha}^{-1}$ dimoxystrobin (BBCH 57-59.)

- 'C' Plant protection: pyraclostrobin $50 \mathrm{~g} \mathrm{ha}^{-1}$ (BBCH 18-19.) + azoxystrobin $100 \mathrm{~g} \mathrm{ha}^{-1}(\mathrm{BBCH}$ 57-59.)

The sunflower hybrid taking part in the experiment was NK Tristan and the plant density was 55 thousand germs $\mathrm{ha}^{-1}$. The experiment was conducted on small randomised plots in four repetitions. Plant pathological infection, average yield and oil content were analysed in the experiment. The results were examined by means of variance analysis and correlation examination by using SPSS 9.0 for Windows programme.

\section{RESULTS AND DISCUSSION}

Changes in the pathological infection of sunflower

Sunflower has an endless number of pathogenic agents, which can cause serious yield losses in average yields either by reducing photosynthetically active leaf area or damaging the stem or disc. During the experiment we could track down the values of the two most frequent pathogenic agents of sunflower, i.e. the leaf infection value (\%) of Diaporthe helianthi and stem-and disc infection value $(\%)$ of Sclerotinia sclerotiorum. In the case of Diaporthe helianthi infection there was a significant difference between the infection results of the treated and not treated (control) plots in both years from which it can be seen that the infection of the plots not treated by plant protection treatments $(36.5-41.25 \%$ in 2017. and $46.7-53.1 \%$ in 2018) exceeded the infection of plots treated by plant protection treatments $(9.5-10.5 \%$ in 2017 . and $11.2-$ $15.8 \%$ were in 2018) many times (Figure 1).

Intensive nutrient supply, especially increased $\mathrm{N}$ dose, results in loosening plant tissues, which is favourable for pathogenic agents. This fact was also justified by means of the variance analysis which proved that plant protection and nutrient supply can cause a significant difference in the values of infection levels (Table 3). The statistical analysis was performed on the average of the two years, because we could not find a statistically justifiable difference between the two years. Due to the more precipitation, the infection was greater in 2018, but it did not exceed the $95 \%$ confidence interval limit.

Figure 1: Changes in the infected by Diaporthe helianthi 2017 and 2018

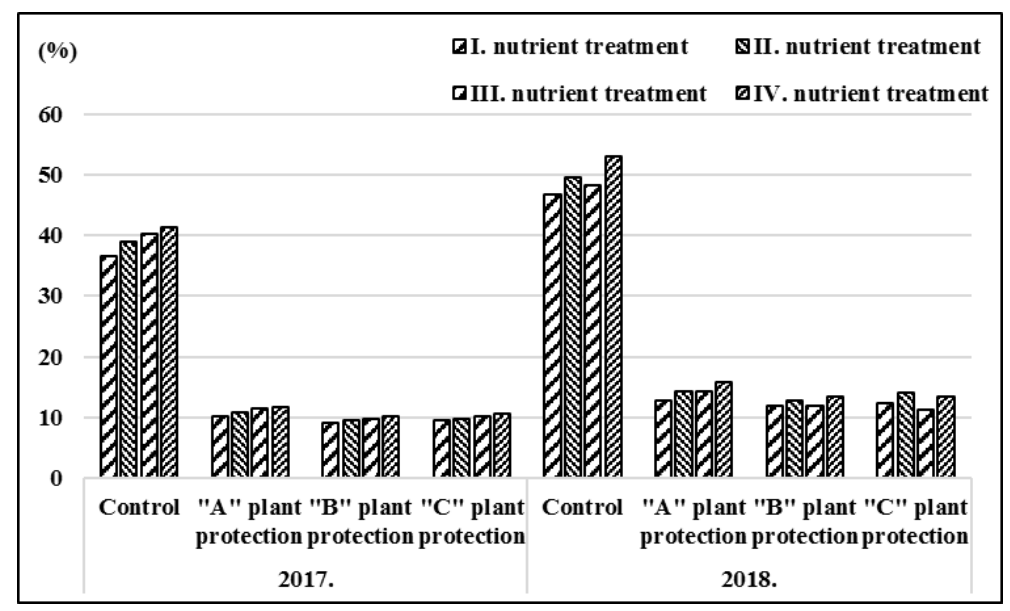

The variance table of Diaporthe helianthi infection values

\begin{tabular}{llllll}
\hline \multicolumn{1}{c}{ Factor } & \multicolumn{1}{c}{ SQ } & FG & \multicolumn{1}{c}{ MQ } & \multicolumn{1}{c}{ F } & Significance \\
\hline Treatment & 19565.016 & 1 & 19565.016 & 16845.215 & $* * *$ \\
nutrient supply & 40.672 & 3 & 13.557 & 11.673 & $* * *$ \\
plant protection & 10124.297 & 3 & 3374.766 & 2905.628 & $* * *$ \\
nutrient * Plant protection & 21.266 & 9 & 2.363 & 2.034 & n. a. \\
Error & 55.750 & 48 & 1.161 & & \\
\hline Total & 29807.000 & 64 & & & \\
\hline
\end{tabular}

***: significant on 0.01 reliability level, $\mathrm{R}^{2}=0.995$ (adjusted $\mathrm{R}^{2}=0.993$ ) 
In examining Sclerotinia sclerotiorum the disc infection values of the fungus were monitored. The extent of disc infection has an extraordinary impact on average yields as it is able to destroy a decisive part of the yield.

Figure 2: Changes in Sclerotinia sclerotiorum disc infection 2017 and 2018

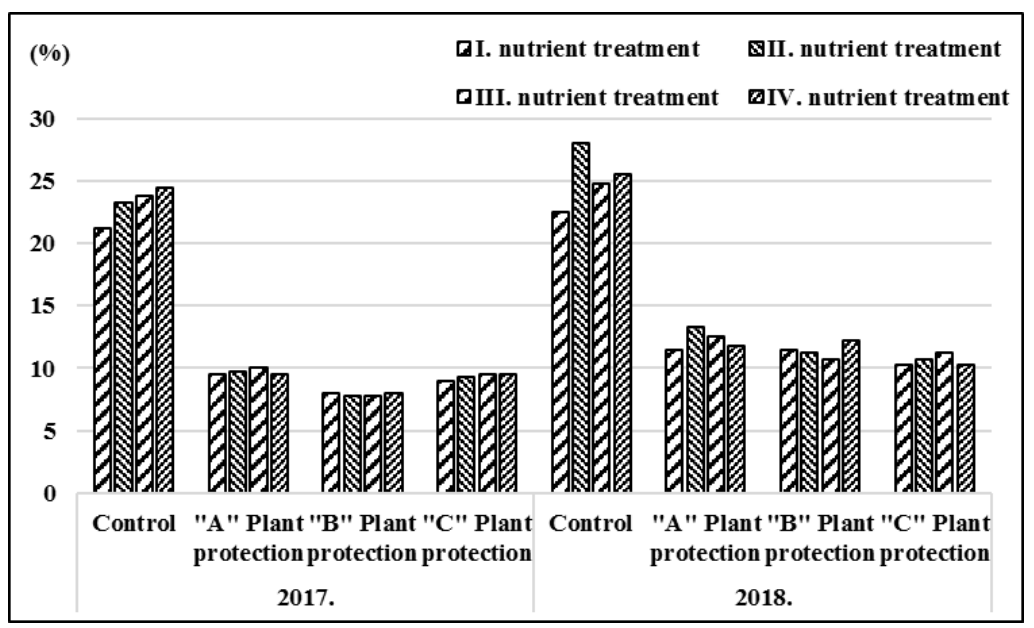

Experiments showed that the infection of $21-24.5 \%$ in 2017 and $22.5-25.5 \%$ in 2018 of the control plot decreased below $7.75-10.0 \%$ in 2017 and 10.25 $13.25 \%$ in 2018 under the conditions of being treated, which is very favourable. The most favourable values were gained in the fungicide combination of ' $B$ ' plant protection treatment in 2017 and ' $\mathrm{C}$ ' plant protection treatment in 2018 (Figure 2).

Between the plant protection treatments ('A'-'B'' $\mathrm{C}$ ' treatments) no significant differences could be experienced and infection levels were ranging from 7.75 to $13,25 \%$. The biggest difference was experienced between the untreated control plots and the plots treated by plant protection treatments, which exceeded significant difference.

Between the nutrient treatment and years we do not find significant differences as well. The statistical analysis of the above-mentioned infection values also supported the fact that only plant protection could influence the level of disc sclerotiny significantly and in a statistically justifiable way. The combined impacts of nutrient supply as well as nutrient supply and plant protection did not reach a significant level.

The variance table of Sclerotinia sclerotorum infection values

\begin{tabular}{|c|c|c|c|c|c|}
\hline Factor & SQ & FG & MQ & $\mathrm{F}$ & Significance \\
\hline Treatament & 1369.000 & 1 & 1369.000 & 1663.595 & $* * *$ \\
\hline nutrient supply & 1.625 & 3 & .542 & .658 & NS \\
\hline plant protection & 902.625 & 3 & 300.875 & 365.620 & $* * *$ \\
\hline nutrient $*$ plant protection & 1.250 & 9 & .139 & .169 & NS \\
\hline Error & 39.500 & 48 & .823 & & \\
\hline Total & 2314.000 & 64 & & & \\
\hline
\end{tabular}

The impact of treatments on the average yields of sunflower

When analysing the results, we can see that chemical fertilizer treatment and fungicide treatment had a significant impact on average yields. It is also obvious that nutrient treatments alone could increase the average yield of sunflower by almost $290 \mathrm{~kg} \mathrm{ha}^{-1}$ in 2017 and $350 \mathrm{~kg} \mathrm{ha}^{-1}$ in 2018, which could further be improved to $450-580 \mathrm{~kg} \mathrm{ha}^{-1}$ in 2017 and $670-920$ $\mathrm{kg} \mathrm{ha}^{-1}$ if supplemented by fungicide treatments (in the same fungicidal treatments). If the effect of fungicide treatments is examined, it can be established that yields increased is at the same nutrient level were 120-420 $\mathrm{kg} \mathrm{ha}^{-1}$ in 2017 and $720-1100 \mathrm{~kg} \mathrm{ha}^{-1}$ in 2018 . The most important difference between the two years is, that in 2018, when there was more precipitation during the growing season, then the plant protection's yieldincreasing effect is greater. The yield-reducing effect of fungal diseases were higher, than 2017.

In this way the yield of the plots treated against pesticides reached the average yield of 3.01-3.67 $\mathrm{t} \mathrm{ha}^{-1}$ in 2017 and $3.75-4.67 \mathrm{t} \mathrm{ha}^{-1}$ in 2018. The largest 
difference in yield was between 'absolute control' (without fertilizer and fungicide) and IV. nutrient treatment of ' $\mathrm{C}$ ' plant protection plots. The yield increase was $710 \mathrm{~kg} \mathrm{ha}^{-1}$ in 2017 in our experiments. In 2018 the highest difference in yield was between 'absolute control' (without fertilizer and fungicide) and IV. nutrient treatment of ' $\mathrm{C}$ ' plant protection plots, similar to the previous year. The yield increase was $1530 \mathrm{~kg} \mathrm{ha}^{-1}$ in 2018.

Figure 3: The impact of nutrient supply on the average yield of sunflower

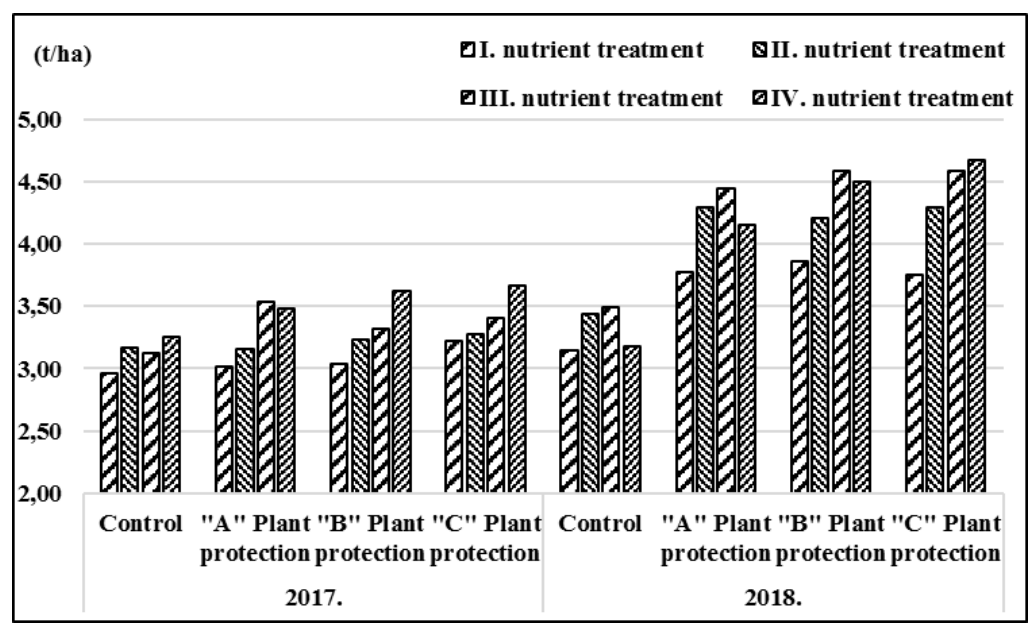

In experiments found, that plots treated by III. and IV. nutrient treatment were able to produce an extraordinary high yield at all plant protection levels, their average yield was fluctuating between 3.12-3.67 $\mathrm{t} \mathrm{ha}^{-1}$ in 2017 and 3.18-4.67 $\mathrm{t} \mathrm{ha}^{-1}$ in 2018 depending on the treatment. Accordingly, we can state that III. and IV. nutrient levels were approaching the optimal nutrient supply of sunflower; yields reached a high level.

During the statistical analysis we could conclude that both nutrient supply and plant protection treatments resulted in significant differences between yields. The LSD5\% value of plant protection treatments is 0.26 in 2017 and 0.29 in 2018, on the basis of which the average yield of ' $C$ ' plant protection technology statistically exceeded the yield of the control plots that had not been given plant protection treatments.

When analysing nutrient supply even stronger impacts were noted where the yield of the control plot without chemical fertilization was significantly increased by III. and IV. nutrient treatments in 2017 and II. III. and IV. nutrient treatments in 2018 (Table 5 and Table 6).

Average yields in different nutrient supplies and plant protection treatments and LSD5\% values

\begin{tabular}{cccccc}
\hline Treatment 2017 & Average t ha $^{-1}$ & LSD5\% & Treatment & Average t ha ${ }^{\text {ka ha-** }}$ & LSD5\% \\
\hline Control & 3,132 & & I. nutrient supply & 3.061 & \\
'A' plant protection & 3,305 & \multirow{2}{*}{0.26} & II. nutrient supply & 3.211 & 0.27 \\
'B' plant protection & 3,307 & & III. nutrient supply & $3.357^{* * *}$ & \\
'C' plant protection & $3,399^{* * *}$ & & IV. nutrient supply & $3.514^{* * * *}$ & \\
\hline
\end{tabular}

*** on $5 \%$ reliability level significant difference

Average yields in different nutrient supplies and plant protection treatments and LSD5\% values

\begin{tabular}{ccccc}
\hline Treatment 2018 & Average t ha $^{-1}$ & LSD5\% & Treatment & Average t ha $^{-1}$ \\
\hline Control & 3,314 & & I. nutrient supply & 3.632 \\
'A' plant protection & 4,162 & & II. nutrient supply & $4.062^{* * *}$ \\
'B' plant protection & 4,297 & 0.29 & III. nutrient supply & $4.286^{* * *}$ \\
'C' plant protection & $4,321^{* * *}$ & & IV. nutrient supply & $4.138^{* * *}$ \\
\hline
\end{tabular}

\footnotetext{
*** on $5 \%$ reliability level significant difference
} 
Fertilization had a most impact in both years in our experiments. The results of the experiment have shown, that high nutrient levels only give high yields, when combined with excellent plant protection. This is because the sunflower is more susceptible to diseases at high nutrient levels.

It can be stated that the excellent plant protection is not enough without excellent nutrition. If any factor is low, then the decrease in yields will occur. The best average yield will be with optimum nutrient supply and excellent plant protection.

The effect of nutrient supply was different from different growing season, because the moisture content of the soil is significantly different. In growing season of 2017 (July to end of August) were less precipitation than optimal. This year the nutrient could not be used well in the experiment for sunflower, therefore only the III. and IV. nutrition level was significant difference in yields of sunflower. In the next year were more precipitation in period of July to end of August, so the nutrient could be utilized in the production of the crop. In this year were the effects of fertilization higher than in 2017, therefore the II. III. and IV. nutrition level was significant.
Similarly, the effect of plant protection is different in 2017 and 2018 as well. During the rainy season, the effect is stronger, because the sunflower is more easily infected when there are more precipitation. Without plant protection the crop is reduced, so its effect is much higher than in a dry year. In both years only ' $C$ ' plant protection had significant effect, but in 2018 a higher disc and leaf infection was measured in July and August.

\section{Oil level measured in sunflower treatments}

In total, it reached $43.80-46.58 \%$ in 2017 and $45.26-46.88 \%$ in 2018 in the treatments. There are no significant differences in oil content although the fact that the oil content of all the treated plots (except ' $B$ ' plant protection technology) exceeded the oil contents measured under control circumstances could be assessed as a trend. It can be seen from the data that in 2017 and 2018 nutrient supply did not have a significant impact on the oil content of sunflower while the examined fungicides were more powerful in influencing the oil content of sunflower and the difference exceeded the significant difference Figure 4.

Figure 4: Oil content \% 2017 and 2018, Szarvas

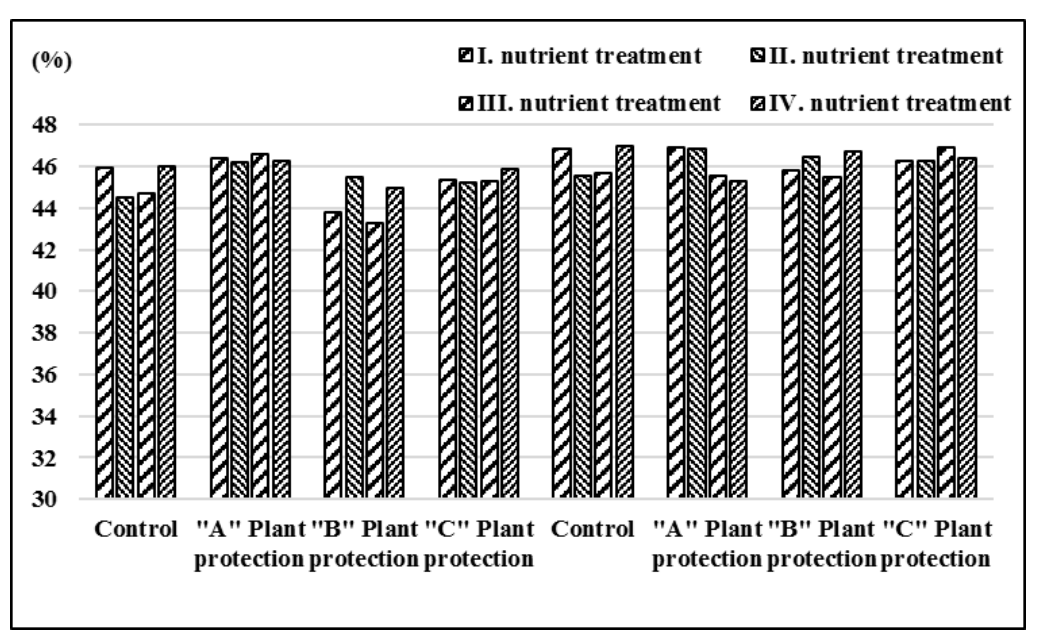

\section{CONCLUSIONS}

Intensive nutrient supply, especially increasing $\mathrm{N}$ dose are favourable for infections. In our experiment we could prove that both plant protection and nutrient supply could result in significant differences in the infection values of Diaporthe helianthi and Sclerotinia sclerotiorum.

The largest infection was measured on plots without plant protection at the highest $\mathrm{N}$ doses, both in leaf and disc diseases. We measured the highest $41.25 \%$ in 2017 and $53.1 \%$ in 2018 Diaporthe helianthi infection, and $24.5 \%$ in 2017 and $25.5 \%$ in 2018 Sclerotinia sclerotiorum disc infection in these plots.

The lowest infection was measured on plots ' $\mathrm{B}$ ' or ' $\mathrm{C}$ ' plant protection on optimal nutrient supply, which was 9.5-11.2\% Diaporthe helianthi infection, and 7.75-10.25\% Sclerotinia sclerotiorum disc infection in our experiments in all years. This result is the same than Radics (2003), and Futó (2013) publications.

We also concluded from the experiment that plant protection and nutrient supply significantly influenced yields that could be reached. Optimal nutrient supply and professional plant protection also led to significant yield increases in the year of the examination.

The lowest yield was obtained in the absolute control plot (without plant protection and without nutrient) in both years, which was $2.96 \mathrm{t} \mathrm{ha}^{-1}$ in 2017 and $3.14 \mathrm{t} \mathrm{ha}^{-1}$. The yields increased due to growing nutrient supply and excellent plant protection. The highest yields were $3.67 \mathrm{t} \mathrm{ha}^{-1}$ in 2017 and $4.67 \mathrm{t} \mathrm{ha}^{-1}$ in 2018 (150 kg ha-1 N, $90 \mathrm{~kg} \mathrm{ha}^{-1} \mathrm{P}_{2} \mathrm{O}_{5}$ and $110 \mathrm{~kg} \mathrm{~K}_{2} \mathrm{O}$ 
active substance and ' $\mathrm{B}$ ' or ' $\mathrm{C}$ ' plant protection), it is similar to Thavaprakash et al. (2003), (Chorey and Thosar, 1997) and Hall et al. (1995) results.

The oil content of sunflower did not change significantly in our experiment, either year.

\section{ACKNOWLEDGMENTS}

This publication is created in EFOP-3.6.1-16-20160016 The specialise of the SZIU Campus of Szarvas research and training profile with intelligent specialization in the themes of water management, hydroculture, precision mechanical engineering, alternative crop production

\section{REFERENCES}

Chorey, A. B.-Thosar, V. R. (1997): Effect of individual production factors on yield of rabi sunflower. PKV Res. J., 21, 169-170.

Devidayal, P.-Agarwal, S. K. (1998): Performance of sunflower hybrids as influenced by organic manures and fertilizers. J. Oilseeds Res., 15, 272-279.

Dhoble, M. V. (1998): Response of sunflower (Helianthus annuus) hybrid to nitrogen and phosphorus in rainfed conditions. Indian J. Agron., 43, 138-141.

Futó, Z. (2008): Különbözö napraforgóhibridek tőszámsủríthetőségének vizsgálata. VI. Alföldi Tudományos Tájgazdálkodási Napok, Mezőtúr. 2008. Október 16-17. CD kiadvány, Summaries 75. p.

Futó, Z. (2013): The effect of nutrient supply and plant protection in yield and oil content of sunflower (Helianthus annuиs L.). Agroecological Journal-Kijev 2013. No 4. pp. 82-87.

Hall, A. J.-Connor, D. J.-Sandras, V. O. (1995): Radiation use efficiency of sunflower crops: effect of specific leaf nitrogen and ontogeny. Field Crop Research. 41:2, 65-77. p.

Ivány, K.-Kismányoky, T.-Ragasits I. (1994): Növénytermesztés Mezőgazda Kiadó, Budapest.
Mallikarjuna, N.-Devakumar, M. V.-Chalapathi, M. V.-Gangadhar Eswar Rao, G. (2000): Integrated phosphorus management for sunflower (Helianthus annuus L.) in Alfisols. Crop Res., 19, 2327.

Novák, A. (2013): Az évjárat hatása a napraforgó növénykórtani tulajdonságaira. Agrártudományi Közlemények, No. 52. 71-75. p.

Pepó, P.-Zsombik, L. (2003): Napraforgó termesztéstechnológiai vizsgálatok legújabb eredményei. Gyakorlati Agrofórum, 14. Évf. 3. szám, 15-16 p.

Radics, L. (2003): Szántóföldi növénytermesztés. Szaktudás Kiadó Ház

Thavaprakash, N.- Senthilkumar, G.-Sivakumar, S. D.- Raju, M. (2003): Photosynthetic attributes and seed yield of sunflower (Helianthus annuus L.) as influenced by different levels and ratios of nitrogen and phosphorus fertilizers. Acta Agronomica Hungarica, 51(2), pp. 149-155.

Vear, F.-Tourvieille, D. (1984): Recurrent selection for resistance to Sclerotinia sclerotiorum in sunflowers using artificial infections. Agronomie, 4: 789-94. 
